\title{
IMMUNOLOGY CORNER
}

\section{What are Autoinflammatory Diseases?}

\author{
Sagar Bhattad
}

\begin{abstract}
Autoinflammatory diseases/syndromes are a new group of heterogeneous diseases characterized by "spontaneous onset of inflammation with no evidence of infection, autoimmunity or allergy and occur due to a defect in the innate immune system." With the advancement of molecular genetics and next-generation sequencing technologies, new diseases are being added to this list every year. In this review, a brief description of a few autoinflammatory diseases would be provided along with a clinical approach. Salient clinical features have been highlighted.
\end{abstract}

Keywords: Autoinflammatory diseases, Blau syndrome, Innate immunity, Periodic fevers.

Pediatric Infectious Disease (2020): 10.5005/jp-journals-10081-1275

\section{INTRODUCTION}

Autoinflammatory diseases/syndromes are a new group of heterogeneous diseases characterized by "spontaneous onset of inflammation with no evidence of infection, autoimmunity or allergy and occur due to a defect in the innate immune system."

\section{Differential Diagnosis in a Febrile Patient}

Conventionally, the list of differential diagnosis in a febrile patient would include

- Infection

- Autoimmunity

- Malignancy

- Allergy (though patients with allergic diseases, often, may not have fever) this list!

One must add "Autoinflammation" as a differential diagnosis to

\section{Autoimmune vs Autoinflammatory: What is the Difference?}

In order to understand this difference, one must be familiar with innate and adaptive immune systems (Table 1).

Autoimmune diseases are characterized by attack on selfantigen and tissues by autoreactive $\mathrm{T}$ and $\mathrm{B}$ cells - a defect in the adaptive immune system.

Autoinflammatory diseases are characterized by damage to one's own tissues by spontaneous inflammation caused by abnormally active innate immune cells (neutrophils, macrophages, etc) - a defect in the innate immune system (Table 2).

Table 1: Key features of innate and adaptive immune system

\begin{tabular}{|c|c|c|}
\hline & $\begin{array}{l}\text { Innate immune } \\
\text { system }\end{array}$ & $\begin{array}{l}\text { Adaptive immune } \\
\text { system }\end{array}$ \\
\hline Key players & $\begin{array}{l}\text { Neutrophils, mac- } \\
\text { rophages, dendritic } \\
\text { cells }\end{array}$ & $T$ cells and $B$ cells \\
\hline Key mediators & Cytokines & Antibodies \\
\hline Line of defence & First line & Second line \\
\hline
\end{tabular}

Division of Pediatric Immunology and Rheumatology, Department of Pediatrics, Aster CMI Hospital, Bengaluru, Karnataka, India

Corresponding Author: Sagar Bhattad, Division of Pediatric Immunology and Rheumatology, Department of Pediatrics, Aster CMI Hospital, Bengaluru, Karnataka, India, Phone: +91 9779433934, e-mail: drsagarbhattad@gmail.com

How to cite this article: Bhattad S. What are Autoinflammatory Diseases? Pediatr Inf Dis 2020;2(3):122-124.

Source of support: Nil

Conflict of interest: None

More than 35 monogenic systemic autoinflammatory diseases (SAIDs) have been described to date. ${ }^{1}$ With the advancement of molecular genetics and next-generation sequencing technologies, new diseases are being added to this list every year. In the next section of this review, a brief description of a few autoinflammatory diseases would be provided. Salient clinical features have been highlighted.

\section{Periodic Fever Syndromes}

The hereditary periodic fever syndromes are a group of monogenic diseases that present with recurrent bouts of fever and associated pleural and/or peritoneal inflammation, arthritis, and various types of skin rash (Table 3).

Table 2: Differences between autoimmune and autoinflammatory diseases

\begin{tabular}{lll}
\hline & Autoimmune diseases & $\begin{array}{l}\text { Autoinflammatory } \\
\text { diseases }\end{array}$ \\
\hline $\begin{array}{l}\text { Key system } \\
\text { involved }\end{array}$ & $\begin{array}{l}\text { Dysfunction of the } \\
\text { adaptive immune } \\
\text { system }\end{array}$ & $\begin{array}{l}\text { Dysfunction of the } \\
\text { innate immune system }\end{array}$ \\
Key players & $\begin{array}{l}\text { Autoreactive T and } \\
\text { B cells }\end{array}$ & $\begin{array}{l}\text { Abnormally active } \\
\text { innate immune cells }\end{array}$ \\
Damage caused by by & $\begin{array}{l}\text { Autoantibodies } \\
\text { Excess cytokines (IL-1, } \\
\text { IL-6 etc.) }\end{array}$ & $\begin{array}{l}\text { Periodic fever } \\
\text { syndromes etc. }\end{array}$ \\
\hline
\end{tabular}

(0) The Author(s). 2020 Open Access This article is distributed under the terms of the Creative Commons Attribution 4.0 International License (https://creativecommons. org/licenses/by-nc/4.0/), which permits unrestricted use, distribution, and non-commercial reproduction in any medium, provided you give appropriate credit to the original author(s) and the source, provide a link to the Creative Commons license, and indicate if changes were made. The Creative Commons Public Domain Dedication waiver (http://creativecommons.org/publicdomain/zero/1.0/) applies to the data made available in this article, unless otherwise stated. 
Table 3: Periodic fever syndromes_A quick review

\begin{tabular}{|c|c|c|c|c|c|c|}
\hline & PFAPA & $F M F$ & TRAPS & NOMID & MWS & HIDS \\
\hline $\begin{array}{l}\text { Duration of each } \\
\text { attack }\end{array}$ & 4-6 days & $<2$ days & $\begin{array}{l}\text { Weeks (usually > } \\
14 \text { days) }\end{array}$ & Continuous & $1-2$ days & 4-6 days \\
\hline Age at onset & $2-5$ years & Childhood & Childhood & Neonatal & Childhood & Less than one \\
\hline $\begin{array}{l}\text { Mode of } \\
\text { inheritance }\end{array}$ & Unknown & $A R$ & $A D$ & $A D$ & $A D$ & AR \\
\hline Gene involved & Not known & MEFV & TNFRSF1A & $N L R P 3$ & NLRP3 & $M V K$ \\
\hline $\begin{array}{l}\text { Key clinical } \\
\text { features }\end{array}$ & $\begin{array}{l}\text { Oral ulcers, } \\
\text { cervical } \\
\text { adenopathy }\end{array}$ & $\begin{array}{l}\text { Erythematous } \\
\text { rash, pain } \\
\text { abdomen }\end{array}$ & $\begin{array}{l}\text { Migratory rash, } \\
\text { pain abdomen, } \\
\text { periorbital edema }\end{array}$ & $\begin{array}{l}\text { Neonatal/ } \\
\text { infantile onset } \\
\text { fevers, deforming } \\
\text { polyarthritis } \\
\text { (epiphyseal bone } \\
\text { formation, urticarial } \\
\text { rashes) }\end{array}$ & $\begin{array}{l}\text { Urticarial skin } \\
\text { rashes, myalgia, } \\
\text { arthralgia }\end{array}$ & $\begin{array}{l}\text { Cervical } \\
\text { lymphadenopathy, } \\
\text { maculopapular rash }\end{array}$ \\
\hline Complications & $\begin{array}{l}\text { None (good } \\
\text { prognosis) }\end{array}$ & Amyloidosis & Amyloidosis & $\begin{array}{l}\text { SNHL, Aseptic } \\
\text { meningitis, } \\
\text { amyloidosis }\end{array}$ & SNHL & \\
\hline
\end{tabular}

PFAPA, periodic fever, aphthous stomatitis, pharyngitis and adenitis; FMF, familial mediterranean fever; TRAPS, TNF receptor-associated periodic fever syndrome; NOMID, neonatal onset multisystem inflammatory disease; MWS, Muckle-Wells syndrome; HIDS, hyper-lgD syndrome; AR, autosomal recessive; $\mathrm{AD}$, autosomal dominant; SNHL, sensorineural hearing loss

\section{Recurrent Fevers and Pharyngitis-Periodic Fever, Aphthous Stomatitis, Pharyngitis, and Adenitis Syndrome}

Periodic fever, aphthous stomatitis, pharyngitis, and adenitis (PFAPA) usually presents between the age of 2 and 5 .

Recurrent fevers, each episode lasting from 4 to 6 days, recurs at a fixed regular interval of 3-6 weeks. Fevers are associated with oral ulcers, tonsillitis, pharyngitis, and enlarged cervical nodes. Throat cultures are sterile. Inflammatory parameters are high during febrile periods.

These children are often misdiagnosed to have recurrent tonsillo-pharyngitis and given antibiotics with no relief. In all children with recurrent fever and pharyngitis, one must keep PFAPA as a possibility. A single dose of prednisolone $(1 \mathrm{mg} / \mathrm{kg})$ causes immediate defervescence and is diagnostic. ${ }^{2}$

\section{Recurrent Fevers and Rashes: Hyper-IgD Syndrome} Hyper-IgD Syndrome (HIDS)

Onset $<6$ months of age.

Recurrent fevers, each episode lasting for 3 to 7 days.

Fevers associated with abdominal pain, diarrhea, nausea, vomiting, and macular rashes.

Diagnosis:

- Elevated mevalonate in urine during acute attacks

- Mutation in MVK gene (autosomal recessive inheritance)

\section{Recurrent Fevers and Pain Abdomen: TRAPS}

TNF Receptor-associated Periodic Fever Syndrome (TRAPS)

Onset in the first decade.

Recurrent fevers-each episode lasts for weeks.

Associated with severe pain abdomen (sterile peritonitis), periorbital edema, conjunctivitis, and erythematous macular rash.

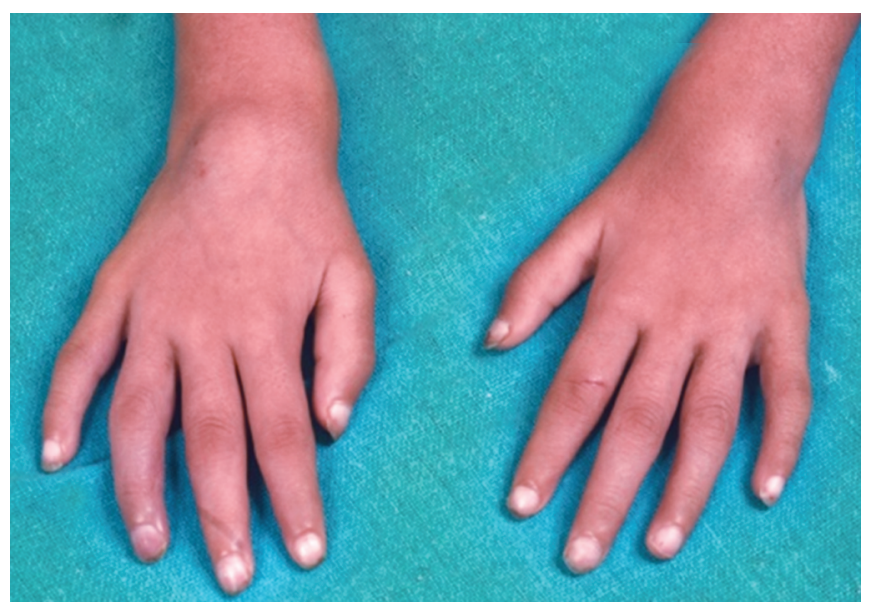

Fig. 1: Boggy swelling of the wrists in a child with Blau syndrome

Diagnosis-high inflammatory parameters, thrombocytosis. Genetic studies-mutation in TNF receptor gene - TNFRSF1A.

\section{Boggy Symmetric Arthritis and Granulomatous Uveitis-Blau Syndrome}

Blau syndrome-early onset sarcoidosis In children with symmetric polyarthritis, features that may point towards Blau syndrome are:

- Boggy swelling of synovium (Fig. 1)

- Granulomatous uveitis

- Rash-micropapular (skin biopsy: non caseating granuloma)

- Family history suggestive of arthritis and/or uveitis in either of the parents (autosomal dominant inheritance).

Blau syndrome is caused by mutation in NOD2 gene. ${ }^{3}$ Aggressive and timely treatment is warranted to prevent serious complications (blindness and permanent deformities). 


\section{Osteomyelitis as a Presentation} Chronic Recurrent Multifocal Osteomyelitis

Onset in childhood.

Children with chronic recurrent multifocal (CRMO) present with fever, bone pain, soft tissue swelling, and increased inflammatory markers. They are often misdiagnosed to have bacterial osteomyelitis. The features that must make one think of CRMO is involvement of multiple bones. Cultures are sterile. Bone scan or whole-body MRI would often pick up sites of bone inflammation with no clinical signs. In any child presenting with second episode of osteomyelitis OR multi-focal osteomyelitis, osteomyelitis affecting clavicle, one must think of CRMO. While there is no role of antibiotics, these children can be treated with NSAIDs and disease modifying anti-rheumatic drugs. ${ }^{4}$

\section{Neurological Presentation}

\section{Aicardi-Goutieres' Syndrome}

Infants presenting with developmental delay and intracranial calcification are often thought to have intrauterine CMV infection (the acronym TORCH syndrome is well known). In children presenting with developmental delay or regression and intracranial calcification, one must keep Aicardi-Goutieres' syndrome (AGS) as a differential diagnosis. These children often have skin rashes and raised inflammatory markers (features that distinguish AGS from congenital CMV disease).
AGS is a group of disease that belongs to type linterferonopathy. These children can be treated with JAK inhibitors and antivirals (reverse transcriptase inhibitors). ${ }^{5}$

\section{Conclusion}

- Every fever is not due to an infection!

- Autoinflammatory diseases are characterized by spontaneous onset of inflammation and occur due to a defect in innate immune system.

- Pattern recognition is the clue in making a timely diagnosis.

\section{References}

1. Havnaer A, Han G. Autoinflammatory disorders: a review and update on pathogenesis and treatment. Am J Clin Dermatol 2019;20(4):539564. DOI: 10.1007/s40257-019-00440-y.

2. Vanoni F, Theodoropoulou K, Hofer M. PFAPA syndrome: a review on treatment and outcome. Pediatr Rheumatol 2016;14(1):38. DOI: 10.1186/s12969-016-0101-9.

3. Caso F, Galozzi P, Costa L, et al. Autoinflammatory granulomatous diseases: from Blau syndrome and early-onset sarcoidosis to NOD2mediated disease and Crohn's disease. RMD Open 2015;1(1):e000097. DOI: 10.1136/rmdopen-2015-000097.

4. Buch K, Thuesen ACB, Brøns C, et al. Chronic non-bacterial osteomyelitis: a review. Calcif Tissue Int 2019;104(5):544-553. DOI: 10.1007/s00223-018-0495-0.

5. Vanderver A, Adang L, Gavazzi F, et al. Janus kinase inhibition in the Aicardi-Goutières syndrome. N Engl J Med 2020;383(10):986-989. DOI: 10.1056/NEJMc2001362. 